\title{
Ground ruptures attributed to groundwater overexploitation damaging Jocotepec city in Jalisco, Mexico: 2016 field excursion of IGCP-641
}

\author{
Pietro Teatini ${ }^{1 *}$, Dora Carreón-Freyre ${ }^{2}$, Gil Ochoa-González ${ }^{3}$, Shujun $\mathrm{Ye}^{4}$, Devin Galloway ${ }^{5}$, \\ and Martin Hernández-Marin ${ }^{6}$
}

\footnotetext{
${ }^{1}$ Department of Civil, Environmental and Architectural Engineering, University of Padova, Via Loredan 20, 35131 Padova, Italy;

*Corresponding author, E-mail: pietro.teatini@unipd.it

${ }^{2}$ Centro de Geociencias, Universidad Nacional Autónoma de México, Campus Juriquilla, Queretaro, Mexico

${ }^{3}$ Western Institute of Technology and Higher Education (Instituto Tecnológico y de Estudios Superiores de Occidente ITESO), Jalisco, Mexico ${ }^{4}$ Department of Hydrosciences, School of Earth Sciences and Engineering, Nanjing University, Nanjing, China

${ }^{5}$ United States Geological Survey, Water Science Field Team, Indianapolis, Indiana, USA

${ }^{6}$ Department of Geotechnics and Hydraulics, Autonomous University of Aguascalientes (Universidad Autónoma de Aguascalientes), Aguascalientes, Mexico
}

IGCP Project 641 (Mechanisms, Monitoring and Modeling Earth Fissure generation and Fault activation due to subsurface Fluid exploitation - M3EF3) held its second international workshop from November 2 to 6, 2016, in Puerto Vallarta and included a two-day field trip to Guadalajara and Jocotepec in the Mexican state of Jalisco (Fig. 1a). M3EF3 is aimed at i) understanding the mechanisms that cause the formation of "ground ruptures", as a response to changes in the stress state in the subsoil, ii) monitoring their occurrence, and iii) developing appropriate approaches to model their formation and growth. Notice that many times it is difficult to discern whether a particular instance of a "ruptured" land surface is due to an earth fissure with a surface manifestation or a surface failure associated with the activation of a pre-existing fault, especially where a fault has not been mapped and where there is no obvious scarp. Therefore, in M3EF3 we preferred to use the term "ground rupture", to refer to both such occurrences.

The occurrence of ground ruptures due to extraction of fluids from the subsurface (principally groundwater, oil and gas) has been observed
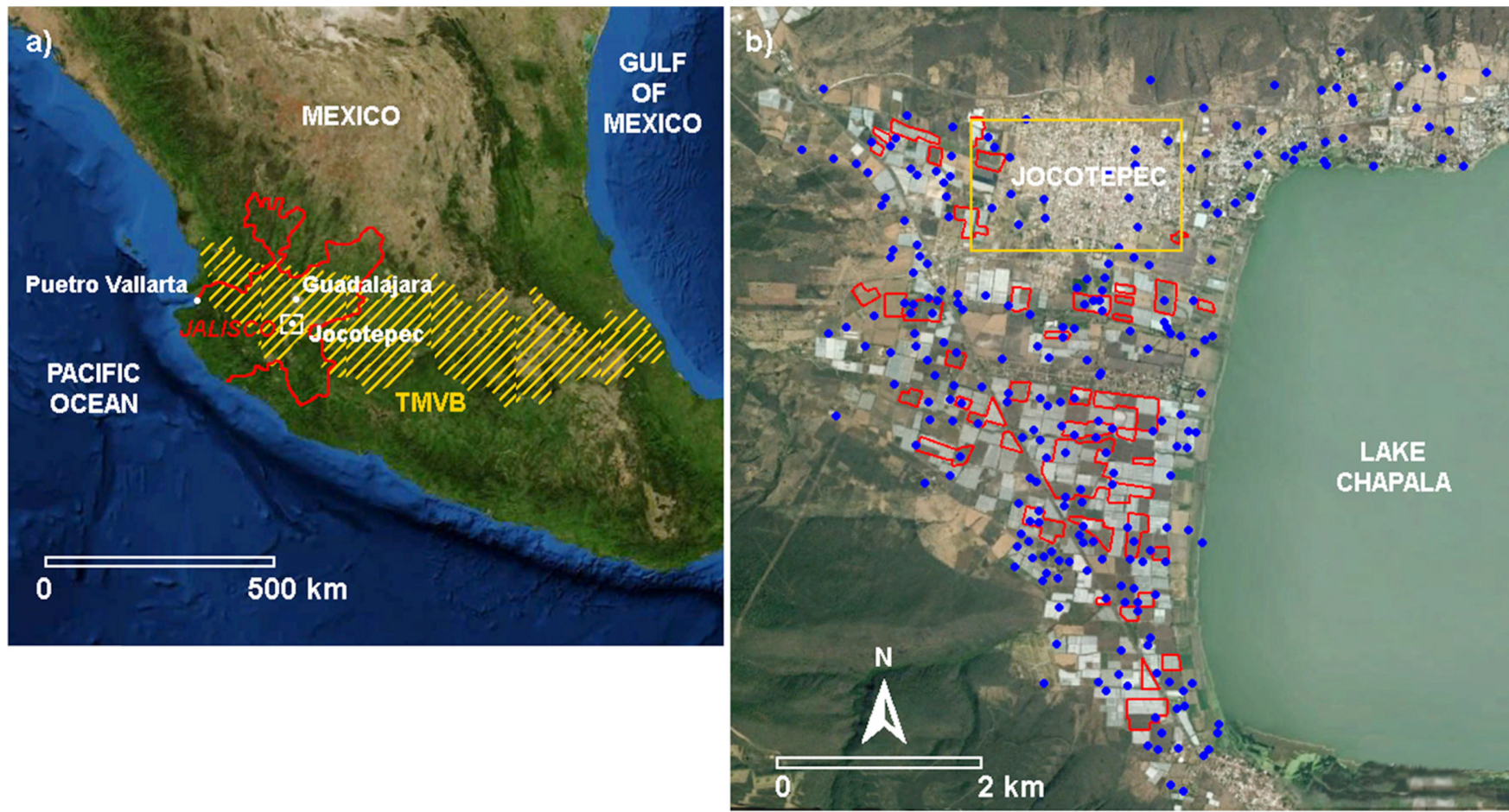

Figure 1. (a) Location of the area of the 2016 IGCP-641 field trip (white square) in the Tran Mexican Volcanic Belt. (b) Landsat image of Jocotepec and its alluvial plain west of the Lake Chapala acquired in March 2016. The large number of greenhouses for blueberry and raspberry production is clearly visible (grey color). The red boxes represent the distribution of greenhouses detectable from a Landsat image of April 2006. No greenhouses were visible in a Landsat image acquired on December 31, 1999. The blue dots represent the location of the wells according to the "Registro Público de Derechos de Agua" updated to 2015 (CONAGUA, 2015) and the yellow box the extent of Figure $3 a$. 
in semiarid sedimentary basins worldwide. Examples documented in the scientific literature include: Mexico (e.g., Carreon-Freyre et al., 2016), southwestern USA (e.g., Holzer, 2010), China (e.g., Ye et al., 2015), India (Srivastava, 2009), Iran (Azat and Shaharam, 2010), Saudi Arabia (Bankher and Al-Harthi, 1999), Libya (Rothenburg et al., 1995). In these countries, fissure generation and ground fractures related to pre-existing fault activation have a strong impact on the development of urban settlements, industrial centers, agriculture and other economic activities.

Located in the Tran Mexican Volcanic Belt (TMVB, Fig. 1a), a major volcanic E-W structure in central Mexico, Jocotepec is a city with approximately 40,000 inhabitants on the westernmost shore of Lake Chapala (Fig. 1b), at an elevation of about 1,540 m above mean sea level. Here, ground rupture associated with land subsidence due to groundwater withdrawal and regional faulting is the main geologic hazard (Zarate-del Valle et al., 2001; Hernandez-Marin et al., 2014).

The city lies within the Chapala graben that is bounded by mountain ranges to the north and west, along the western shore of Lake Chapala that occupies much of the graben plain. Recent tectonic activity has been documented along the flanks of the Chapala graben, located near an active triple junction where deformation has created a pattern of tectonically tilted blocks (Rosas-Elguera et al., 1997; RosasElguera and Urrutia-Fucugauchi, 1998). The geometry of the Lake Chapala basin changed over time since Late Miocene-Early Pliocene to Early Pleistocene. The original large lacustrine basin named Jalisco paleo-lake was affected by tectonic and volcanic activities that caused progressive isolation of different paleo-depressions (Rosas-Elguera and Urrutia-Fucugauchi, 1998). Therefore, the subsoil materials are composed of lacustrine high compressible dark silts and clays, up to $600 \mathrm{~m}$ thick, beneath most of the paleo-lake region (Aparicio, 2001;
Zarate-del Valle, 2001). The Jocotepec area is bounded by a west-east south-dipping active normal fault that, with a trace more than $15 \mathrm{~km}$ long (Fig. 2), has influenced sedimentation rates throughout the basin (Fernex et al., 2001).

The near surface deposits filling the graben are related to the piedmont-fluvial morphology (poorly sorted volcanic gravels and sands), alluvial fans (fluvial silts, rounded sands and gravels), and lacustrine soils (silts and clays) (Zarate-del Valle et al., 2001). The sediments underlying the area constitute a multilayered aquifer system with a cumulative thickness of a few hundred meters. The sediments beneath the urban area may represent a transition between the relatively less compressible piedmont-fluvial deposits and the relatively more compressible alluvial-lacustrine deposits, with possibly abrupt changes between the two sequences (Hernandez-Marin et al., 2014).

Lake Chapala is the major Mexican fresh water reservoir. In 1897 a historical drought reduced the lake surface to its actual size, with an approximate $70 \mathrm{~km}$ length, $20 \mathrm{~km}$ width, and a mean $6 \mathrm{~m}$ depth depending on the season and the annual rainfall (Aparicio, 2001; Zarate del Valle et al., 2001). The lake supplies water to the inhabitants of Guadalajara, the second largest city in Mexico, and a frequent conflict over its water use occurs with the irrigation and industrial sectors. A considerably low recharge to Lake Chapala was observed over the last three decades, with the middle-lower Lerma river basin, i.e., the hydrologic watershed where Lake Chapala and Jocotepec are located, which is one of the most over-exploited regions in Mexico in terms of water resources (Aparicio, 2001). Here, the aquifer systems have been largely exploited to supply water for agricultural and, secondarily, potable purposes. According to CONAGUA, in 2000 approximately 4000 wells extracted more than $600 \mathrm{Mm}^{3} /$ year in this region (Aparicio, 2001). Figure $1 \mathrm{~b}$ shows the location of the wells authorized by the

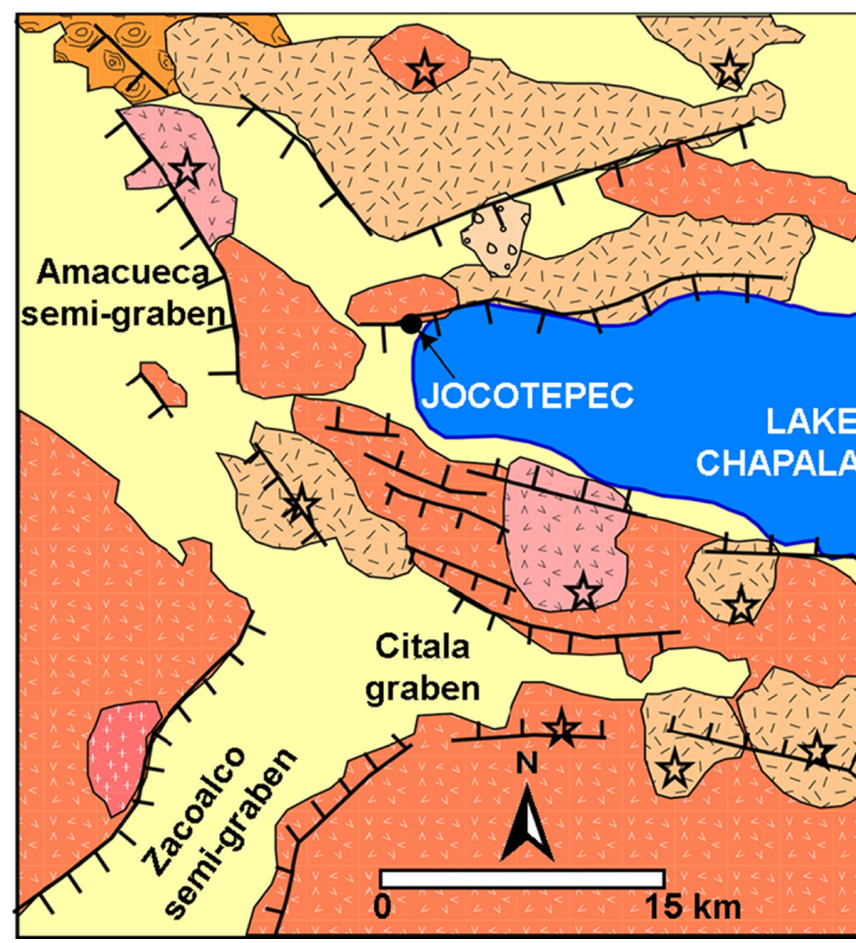

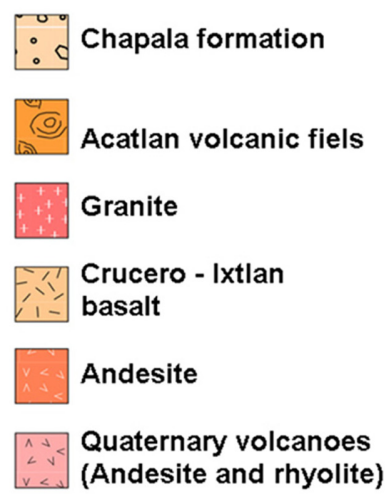
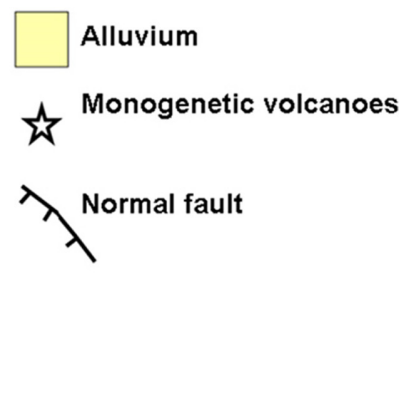

Figure 2. Major tectonic structures and main geologic units surrounding Jocotepec (re-drawn after Rosas-Elguera and Urrutia-Fucugauchi, 1998). 
national water agency (CONAGUA, 2015) around Jocotepec: more than 100 wells are drilled in the $\sim 16 \mathrm{~km}^{2}$ plain adjacent to the lake. According to the local water agency (Comisión Estatal del Agua del Estado de Jalisco, 2015), more than $75 \%$ of the pumped groundwater has been used for extensive irrigation due to recently established berry cultivation, which requires significant quantities of water during most of the year. Groundwater is preferred by the farmers to lake water because i) of the better quality of the former and ii) well construction and maintenance is more easily managed by each land owner rather than depending on public conduits that could distribute the surface water to the community. A remote sensing investigation with a series of Landsat images acquired between 1984 and 2016 clearly shows the enlargement of the berry greenhouses which have been developed since 1999 (Fig. 1b) and presently (2016) occupy more than half of the entire plain. The consequent significant piezometric lowering has caused dramatic land subsidence in the area. Land subsidence in this area was first observed in 1990 but was not documented until 2007 by Castillo-Aja and Valdivia-Ornelas (2007). In 2012, Hernandez-Marin et al. (2014) used levelling surveys to calculate a subsidence rate of as much as $\sim 10 \mathrm{~cm} /$ year in downtown Jocotepec.

The presence of regional faults that affect a relatively shallow bedrock and, a highly heterogeneous aquifer system are the main factors that favor differential surficial deformation in subsiding basins and the consequent occurrence of ground ruptures (Holzer and Pampeyan, 1981; Sheng et al., 2003). Indeed, these geological features characterize the Chapala graben and, as expected, Jocotepec is profoundly threatened by ground ruptures. Figure 3 a shows the trace of the three 2-km long ruptures crossing Jocotepec as mapped by Hernandez-Marin et al. (2014) and visited by participants of the IGCP-641 field trip. The ground ruptures have similar orientation and kinematics as the regional faults delimiting the graben on which the city is constructed. The strong displacement gradients affect roads, canals, and walls of dozens of masonry houses intersected by the ground ruptures. Figure $3 \mathrm{~b}$ shows a photo taken during the excursion from the footwall of rupture B (see the site in Fig. 3a) toward rupture C, which is about $200 \mathrm{~m}$ to the south and visible in the distance. The portion of the village between the two ruptures subsided by approximately $1.5 \mathrm{~m}$ more than portions beyond the two ruptures.

Examples of the typical effects of ground ruptures on the village structures and infrastructures are shown in Figure 4. Destroyed houses have been abandoned, and others have been repaired and must be continuously repaired as a consequence of the ongoing movement of the ruptures. The road pavement in the vicinity of the scarps was changed from traditional asphalt to more flexible concrete paver blocks (Fig. $3 b)$ increasing the adaptability to differential movements.

The field-trip participants discussed many important aspects related to the hazards posed by the ruptures in the context of the geologic structure and hydrogeologic setting of the area, including the tectonic control of the subsidence pattern and the possible effects of a new well recently drilled in the city center to supply potable water. At a first glance, land subsidence and associated ground ruptures seem to be caused by a combination of three factors: groundwater withdrawal, tectonics, and natural consolidation of silty-clayey materials. The participants identified a few key actions that could be taken to address the problem such as carrying out careful investigations and field studies to improve the characterization of the principal mechanisms driving the differential displacements in Jocotepec and understanding of the possible hydraulic connection between the lake and the aquifer. The spatial and temporal distributions of piezometric drawdown and land subsidence in the entire western plain need to be determined and monitored. Ideally, modeling tools need to be developed to guide sustainable alternatives for managing the groundwater resource while taking into account the groundwater demand from agriculture, which is one of the main sources of economic income in the area. In agreement

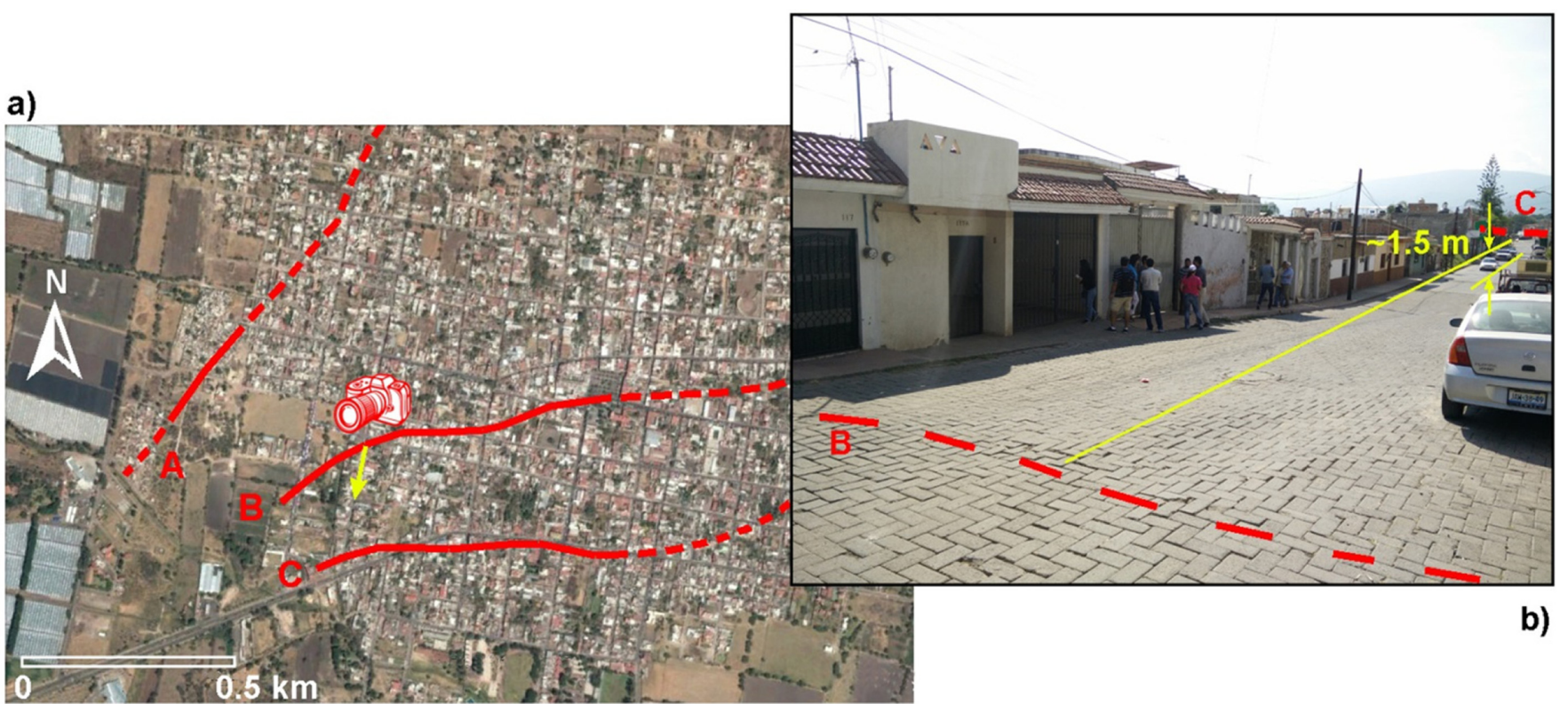

Figure 3. (a) Aerial view of Jocotepec with the trace of the major known (solid red lines) and inferred (dashed red lines) ground ruptures mapped by Hernandez-Marin et al. (2014). The trace of the area is provided in Figure 1b. (b) Photo from the IGCP-641 field trip on November $\boldsymbol{b}^{\text {th }}$, 2016, highlighting land subsidence of about $1.5 \mathrm{~m}$ between ruptures $B$ and $C$ which are about $200 \mathrm{~m}$ apart. The photo location and direction are shown in (a). 

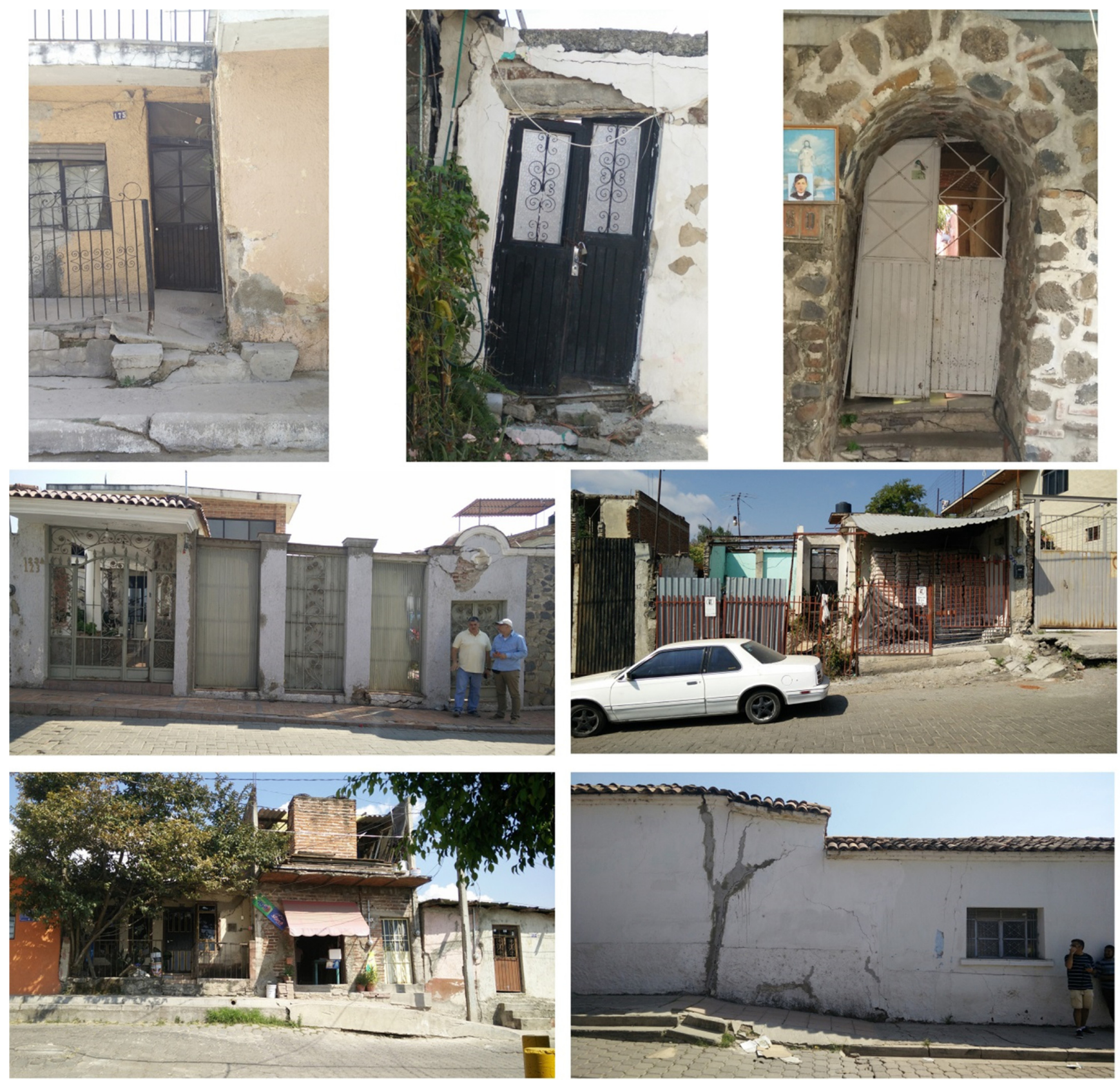

Figure 4. Photos from the IGCP-641 field trip on November $6^{\text {th }}$, 2016, showing the damages to Jocotepec houses and roads caused by ground ruptures.

with the Western Institute of Technology and Higher Education (Instituto Tecnológico y de Estudios Superiores de Occidente - ITESO) in Guadalajara, a program was planned for 2017 to enhance public awareness and knowledge exchange between geoscientists and local stakeholders regarding the anthropogenic origin of the ground ruptures in Jocotepec due to groundwater overexploitation.

\section{Acknowledgements}

This manuscript benefitted from the thoughtful reviews provided by Mihail Popescu (editor, Episodes), Rob Carruth (U.S. Geological Survey), Mariano Cerca (Universidad Nacional Autónoma de Méx- ico, Juriquilla), Roberto Tomás Jover (Universidad de Alicante) and Michelle Sneed (U.S. Geological Survey). This work is a contribution of IGCP project 641 sponsored by UNESCO-IUGS.

\section{References}

Aparicio, J., 2001, Hydrology of the Lerma-Chapala watershed. In: Hansen, A.M., and van Afferden, M. (Eds.), The Lerma-Chapala Watershed: Evaluation and Management. Springer, New York, pp. 3-30.

Azat., E., and Shahram, S., 2010, Land subsidence and fissuring due to ground water withdrawal in Yazd-Ardakan Basin, Central Iran. World Academy of Science, Engineering and Technology, v. 71, pp. 535-538. Bankher, K.A., and Al-Harthia, A.A., 1999, Earth fissuring and land sub- 
sidence in Western Saudi Arabia. Natural Hazards, v. 20, pp. 21-42.

Carreon-Freyre, D., Cerca, M., Ochoa-Gonzalez, G., Teatini, P., and Zuñiga, F.R., 2016, Shearing along faults and stratigraphic joints controlled by land subsidence and hydraulic gradient in the Valley of Queretaro, Mexico. Hydrogeology Journal, v. 24, pp. 657-674.

Castillo-Aja, M.R., and Valdivia-Ornelas, L., 2007, Amenazas por agrietamiento en el Valle de Tesistán (Risks due to cracking in the Valley of Tesistan). Universidad de Guadalajara.

Comisión Estatal del Agua del Estado de Jalisco, 2015, Ficha Técnica Hidrológica del Municipio de Jocotepec. $50 \mathrm{p}$.

CONAGUA, 2015, Subsistem de visualización, en Google Earth, de las capas de datos geograficos de los aprovechamientos inscritos del Registro Público de Derechos de Agua (REPDA). http://siga.conagua.gob.mx/ REPDA/Menu/FrameKMZ.htm

Fernex, F., Zárate-del Valle, P., Ramírez-Sánchez, H., Michaud, F., Parron, C., Dalmasso, J., Barci-Funel, G., and Guzman-Arroyo, M., 2001, Sedimentation rates in Lake Chapala (western Mexico): possible active tectonic control. Chemical Geology, v. 177, pp. 213-228.

Hernandez-Marin, M., Pacheco-Martinez, J., Ramirez-Cortes, A., Burbey, T.J., Ortiz-Lozano, J.A., Zermeño-de-Leon, M.E., Guinzberg-Velmont, J., and Pinto-Aceves, G., 2014, Evaluation and analysis of surface deformation in west Chapala basin, central Mexico. Environmental Earth Sciences, v, 72, pp. 1491-1501.

Holzer, T.L., and Pampeyan, E.H., 1981, Earth fissures and localized differential subsidence. Water Resources Research, v. 17, pp. 223-227.

Holzer, T.L., 2010, Implications of ground-deformation measurements across earth fissures in subsidence areas in the southwestern USA. In: Carreón-Freyre, D., Cerca, M., and Galloway, D.I. (Eds.), Land Subsidence, Associated Hazards and the Role of Natural Resources Development. International Association of Hydrological Sciences Publication,
339, pp. 9-19.

Rosas-Elguera, J., Ferrari, L., López-Martinez, M., and Urrutia-Fucugauchi, J., 1997, Stratigraphy and tectonics of the Guadalajara region and triple-junction area, western Mexico. International Geology Review, v. 39, pp. 125-140.

Rosas-Elguera, J., and Urrutia-Fucugauchi, J., 1998, Tectonic control of the volcano-sedimentary sequence of the Chapala graben, Western Mexico. International Geology Review, v. 40, pp. 350-362.

Rothenburg, L., Obah, A., and El Baruni, S., 1995, Horizontal ground movements due to water abstraction and formation of earth fissures. In: Barends, F.B.J., Brouwer, F.J.J., and Schroder, F.H.(Eds.), Land Subsidence by Fluid Withdrawal, by Solid Extraction; Theory and Modelling, Environmental Effects and Remedial Measures. International Association of Hydrological Sciences Publication, 234, pp. 239-249.

Sheng, Z., Helm, D.C., and Li, J., 2003, Mechanisms of earth fissuring caused by groundwater withdrawal. Environmental Engineering Geoscience, v. 9, pp. 313-324.

Srivastava, D., 2009, Ground fissures in Uttar Pradesh - a review. Earth Science India, October, 2009. Available at http://www.earthscienceindia.info/ Popular_archive.aspx

Zarate-del Valle, P.F., Michaud, F., Parron, C., Solana-Espinoza, G., Israde-Alcantara, I., Ramirez-Sanchez, H.U., and Fernex, F., 2001, Geology, sediments and soils. In: Hansen, A.M., and van Afferden, M. (Eds.), The Lerma-Chapala Watershed: Evaluation and Management. Springer, New York, pp. 31-57.

Ye, S., Wang, Y., Wu, J., Teatini, P., Yu, J., Gong, X., and Wang, G., 2015, Characterization of earth fissures in South Jiangsu, China. In: Daito, K., and Galloway, D. (Eds.), Prevention and Mitigation of Natural and Anthropogenic Hazards due to Land Subsidence. International Association of Hydrological Sciences Publication, 372, pp. 249-253. 